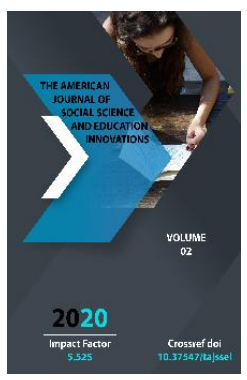

\title{
Text Selection Issue For Parallel Corpus
}

\author{
Rustam Abdurasulovich Karimov \\ Senior Lecturer, Department Of Foreign Languages In Natural Sciences, Foreign Languages \\ Faculty, Bukhara State University, Bukhara, Uzbekistan
}

Journal Website:

http://usajournalshub.c om/index,php/tajssei

Copyright: Original content from this work may be used under the terms of the creative commons attributes 4.0 licence.

\section{ABSTRACT}

It is known that the basis of any corpus is its units. Typically, texts of different genres are selected as the corpus unit to ensure the representativeness of the corpus. Therefore, when creating any language corpus, first of all, the principles of selection of texts that are part of it should be defined. Parallel corpus units consist of texts that have been translated one or more times from the original. Which topic and genre text to choose for the parallel corpus is determined by the purpose of the compiler?

\section{KEYWORDS}

Language corpus, parallel corpus, direct and indirect translations, author, translator.

\section{INTRODUCTION}

Parallel corpuses can represent a one-way translation (from Uzbek to English only) or a two-way translation (from Uzbek to English, from English to Uzbek). When selecting a text for the Uzbek-English parallel corpus, it is advisable to collect both direct and indirect translations from Uzbek into English and from English into Uzbek. Thus, the Uzbek-English parallel corpus consists of two blogs: the Uzbek-English language blog (1), the EnglishUzbek language blog (2). 
The materials for these blogs are not the same: the first blog contains works of art translated from Uzbek into English; the second blog consists of works translated from English into Uzbek. Of course, in the search engine, the works selected for search by genre, period of creation, author and translator of the works require selection in this regard. We will focus on these aspects, which are identified on the basis of extralinguistic tags, in the following sections of the work.

\section{LITERATURE REVIEW}

M.Kholbekov, a specialist in translation theory and a skilled translator, provides valuable information about translations from foreign languages in the twentieth century. According to him, in the history of world civilization, the twentieth century was called the "century of translation" (P.-F. Kaye). Uzbek translation, which has a thousand-year history, has also achieved unprecedented results in the last century, introducing our people to the masterpieces of world literature.

From Cholpon's Shakespeare (Hamlet), Osman Nosir's Lermontov (Demon), Oybek's Pushkin (Eugene Onegin), Erkin Vahidov's Gyote (Faust), Abdulla Aripov's Dante (Hell), Kadir Mirmukhamedov's translations from Homer (the lliad) became important events in the history of our literature, as well as stable translations of the above works into our language[1. Xolbekov M. - Pp. 16-42].

Continuing the series of translated works by M. Kholbekov, Djon Golsuorsi, Sommerset Moem, Tomas Sternz Eliot, Richard Oldington, Oldos Xaksli, Ilvin Vo, Ayris Myordok from the English literature of today's reader; Uilyam Folkner, Ernest Xeminguey, Jon Steynbek, Richard Rayd, Jon Apdayk, Deyvid Selinjer,
Uilyam Stayron from american literature; Giyom Apolliner, Marsel Prust, Andre Jid, Antuan de Sent-Ekzyuperi, Alber Kamyu, Fransua Moriak, Natali Sarrot, Klod Simon, Jan-Mari Gyustav Le Klezio, Patrik Modiano from French literature; Tomas Mann, Lion Feyxtvanger, Arnold Stveyg, Bertolt Brext, German Gesse, Genrix Byoll, Krista Volf, Gyunter Grass from German literature; he also notes that he has been able to read translations of Xorxe Luis Borxes, Gabriel Garsia Markes, Umberto Eko, Xulio Kortasar, Alexo Karpenter, Kadzuo Isiguro, Mo Yan, Lao She, Xaruki Murakami's works. He also considers the fact that Gegel, Kerkegor, Nistshe, M.Baxtin, R.Bart, Xose Ortega-iGasset, M.Xaydegger, A.F.Losev have been acquainted with the views of others on literature and the literary process through the magazine "World Literature" as a positive event for the literary environment.

So, there is a set of translations that can serve as a linguistic basis for the creation of a parallel Uzbek-English corpus.

\section{ANALYSIS}

Shakespeare, John Galsworthy, Sommerset Moem, Thomas Sternz Eliot, Richard Oldington, Oldos Huxley, Ivlin Waw, Iris Murdoch from English Literature for the second blog of the Parallel Corpus, which includes works translated from English into Uzbek; translations of the works of William Faulkner, Ernest Hemingway, John Steinbeck, Richard Wright, John Updike, David Selinger, William Styron can be obtained from American literature.

M. Kholbekov emphasizes that it is impossible not to pay attention to this problem. According to him, in the pages of the 
magazine are published mainly translations of works of foreign writers into Russian.

From now on, World Literature should become a publication that promotes direct translations from the original. For example, in recent years, the magazine has featured examples from the work of the medieval French poet François Ion, the beggars of English and American Romantic poetry, George Byron, and Edgar Allan Poe. A reader unfamiliar with the original and Russian translation texts read the above translations and came to the conclusion that Vion, Byron, Edgar Allan Poe had actually written so. However, when these translations are compared with the original and the Russian translation texts, one can observe how freely the poet-translators moved, and, as a result, how far they moved from the original.

M.Kholbekov, using the idea that in the translation of poetry the translator becomes a rival of the author, emphasizes that the translator can write a poem in sync with the text of the original in the native language, but does not give such a concept.

Hence, the text selected for the second blog of the parallel corpus should be translated from the original (English). The reasons for this are explained below.

The poem "On this Day I complete my Thirtysixth year, 1824" by the English poet George Byron, translated by $Z$. Morozkina, reads as follows:

Других не властный волновать,

Я сам бесстрастен должен быть.

Но и без отклика, опять

Хочу любить.

The translator Abdul Hamid translated the above verse as follows:

Kundan-kunga yaqin intiho,
Esar fasli xazon yellari

Qaro qabr kutar och,yuho, Bag'rimda tek armon unlari.

M.Kholbekov, a respected translator-critic, notes that this work of poetry has been translated three times; comparing the translations, he concludes: "While the poets Miraziz Azam and Husniddin Sharipov wrote that they translated from Russian, Abdul Hamid did not say from which language he translated. It is clear how far all three translations have moved away from the Russian text in place of the original. We compared the above four to the English text, perhaps wondering if Abdul Hamid had made his translations from the original. However, it is also clear that it is far from the English text. In the English text, the poem has the same content and appearance as in the Russian translation:

It is time this heart should be unmoved, Since others it hath ceased to move:

Yet, though I cannot be beloved, Still let me love!

The bottom line is that we now need to move directly from the original language to the translation. The first direct translations appeared in the last quarter of the last century. Goethe's "Sufferings of Young Werther" and Bruno Apitz's "In the Claws of Wolves" by Yanglish Egamova, "Devon of West and East" by Sadriddin Salimov, Victor Hugo's "Songs of the East" by Sharofat Botirova, F. Garcia-Lorca's "Most Sad Song" by Shavkat Rahmon was translated from the original. Our poets Jamal Kamal and Abdullah Sher also used the original to translate the plays of W. Shakespeare and J. Byron.

The good work that began in the early years of our independence has continued very slowly, in our view. However, in the words of 
translator Zuhriddin Isomiddinov, "the time has come when translation from foreign literature is at its peak."

\section{DISCUSSION}

Indirect translation of M.Kholbekov Ibrahim Gafurov, Nizam Kamilov, Jamol Kamol, Muhammad Ali, Abdulla Sher, Mahkam Mahmudov, Yanglish Egamova, Shoazim Munavvarov, Suvon Meli, Mirzaali Akbarov, Zuhriddin Isomiddinov and other lecturers; that he was not involved in supervising master's dissertations, and that such experienced scholars did not even write textbooks and manuals with masters who knew foreign languages.

"Today, translation is one of the main factors of interlingual and intercultural communication. In short, "translation introduces the nation to the world," paving the way for us to participate directly in the process of international globalization. We must never forget that."

There is a saying, "Shakespeare is infinite". The word belongs to the pen of the great German poet Johann Wolfgang Goethe. Indeed, the legacy of William Shakespeare, a great exponent of English Renaissance literature and theatrical art, has been captivating the peoples of the world for four centuries. In Uzbekistan, too, the name of Shakespeare, his works are well-known and popular, deeply rooted in the hearts of readers and viewers. Almost all of the royal works created by Shakespeare over the past eighty years have been translated into our language and presented to the reader in a number of editions. During the period of independence, the publishing house "Fan" published another three-volume "Selection" of Shakespeare's works, translated by the poet Jamal Kamal, and did another good deed in this regard.

The translation of Shakespeare's creative heritage is also significant in that it served as a material for the creation of the first UzbekEnglish parallel corpus. The question arises: if there is a translation of the work, how important is it to re-create a parallel corpus from the finished product? Since the corpus is designed to collect ready-made translations, not to translate, what does it mean for science, the user, the theory of translation? Isn't that an unnecessary process and product?

The answers to the above pertinent questions are as follows:

1) the existing world parallel corpus is based on ready-made translations;

2) combining the translation into a parallel body allows to read the original work and the translation of the whole work side by side;

3) most importantly, the parallel corpus is the most optimal way to observe how this or that unit (simple sentence, compound sentence, phrase, phraseological unit, slang, metaphor) is expressed in the original and in translation.

Therefore, in the choice of material for any parallel corpus, the principle of obtaining a variant of the translation made directly from the original prevails. Because the units listed above lose their value in indirect translation, in this case the parallel corpus cannot fully perform its function.

In the history of Uzbek translated literature, the translations by Ogahiy, Cholpon, Oybek, Usmon Nosir, Gafur Gulom, Mirtemir, Mirzakalon Ismoiliy, Ozod Sharofiddinov, Erkin Vohidov, Abdulla Aripov, Qodir Mirmuhamedov, Ibrahim Gafurov are 
noteworthy; they are important in that the parallel corpus is a valuable supply for the linguistic base. It is possible to obtain only a directly translated copy of works that have been re-translated several times, or to include indirect translations for comparison. This, of course, stems from the corpus designer's intention to create a research or illustrative corpus.

If we talk about the experience of translating from Shakespeare's work, the tragedy of the author "Hamlet" ("Hamlet", 1600-1601) is the most widely translated work in the world. Indeed, the point that touches the heart of the reader and the audience in the play is Hamlet's monologue.

Confronted with the bitter truth of life, which had clashed with innumerable fiqhs, and which had struck at the pure notions of existence and man, Hamlet was faced with the question of "either life or death."[ Xolbekov M. - Pp. 16-42.]

One of Shakespeare's masterpieces is the tragedy of Romeo and Juliet (Romeo and Juliet, 1597). It was translated into Russian at different times by T. Shchepkina, Copernicus and B. Pasternak. Both translations have so far been published in advance and performed in theaters. The tragedy was first translated into Uzbek by Maqsud Shaykhzoda in 1949, and forty-two years later (Othello's 1991 book, Romeo and Juletta, does not contain a translation) by Jamal Kamal. The prince translated the work into Uzbek from the Russian version of B. Pasternak, and critics say that the Uzbek translator also used the Azerbaijani translation of Jafar Jobborli.

For example, in the final of the tragedy, the final word of the ruler of Verona, Prince Eskal (Escalus, Prince of Verona - Eskalus [Latin],
Prince of Verona) is actually written as follows:

Prince:

A glooming peace this morning with it brings.

The Sun for sorrow will not show his head: Go hence, to have more talk of these sad things.

Some shall be pardon'd, and some punished.

For never was a story of more woe

Than this of Juliet and her Romeo.

[The tomb is closed.] Exeunt.

Now we quote the above verses in $B$.

Pasternak's translation:

\section{Князь:}

Сближенье ваше сумраком объято

Сквозь толщу туч не кажет солнце глаз.

Пойдем, обсудим сообща утраты

И обвиним иль оправдаем вас.

Но повесть о Ромео и Джульетте

Останется печальнейшей на свете...

Уходят.

Maqsud Shaykhzoda translated these verses as follows:

Bek:

Hammangizga tong keltirdi motamsaro sulh, Hatto qalqmoq istamaydi alamli quyosh.

Yuring, hali kengash qurib o'ylamoq kerak -

Kimga - bizdan iltifotu kimlarga jazo!

Romeo va Julyettaning qissasidan ham,

G'amli qissa ko'rgan emas tarixda olam!

Ketadilar.

Jamal Kemal translated the prince's speech from the original as follows:

Bek:

Shuning bilan tong keltirdi g'amgin osoyish, G'amdan boshin ko'tarolmay, qiynalar quyosh.

Yuring, gaplashaylik yana, etaylik tayin, Kimni kechiramiz, kimga bergaymiz jazo.

Romeo va Julyettaning ishqidek, evoh Qayg'uli bir muhabbatni ko'rmamish dunyo! Ketishadi. 


\section{CONCLUSION}

We have given the observations of $M$. Kholbekov in detail above. The reason for this was to recall once again the learning process of translation. The researcher, who aims at the comparative study of translations, carefully examines all its copies; finds and compares each piece from this or that option. The expert searches each passage dozens of times to show the advantages and disadvantages of translation. If the software of the UzbekEnglish parallel corpus is created, and the linguistic base collected for the corpus is subordinated to a perfect and convenient search system, the researcher's work will be facilitated by automation; the processes of comparison and comfortable become clearer; the conclusions will be clear.

Therefore, only the results of the linguistic corpus-based analysis of the issues studied in linguistic research conducted abroad - the conclusions based on statistics - are recognized by the scientific community. The conclusion reached without relying on the language corpus is considered non-objective.

\section{REFERENCES}

1. Xolbekov M. Translation and translation studies in Uzbekistan (1991-2016) // Foreign philology. - 2016. - №3. - Pp. 16-42.

2. Xamroeva Sh. Linguistic bases of formation of the Uzbek language author's corpus: Philol. fan. Ph.D. (PhD) dissertation. - Buxoro, 2018. - Pp. 72-73.

3. Zakharov V.P., Bogdanova S.Y. Corpus linguistics. - Irkutsk: IGLU, 2011. - P.36.

4. Buntman N.V., Zaliznyak A.A., Zatsman I.M., Kruzhkov M.G., Loshilova E.Yu.,
Sichinava D.V. Information technologies of corpus research: principles of building cross-linguistic databases // Informati and its applications. - 2014, volume 8 , issue 2. Pp. 98-110. DOI: https://doi.org/10.14357/19922264140210. (Boot options: IP: 213.230.114.157. August 17, 2019 8:50:00 PM)

5. Loiseau S., Sitchinava D. V., Zalizniak A. A., Zatsman I.M. Information technologies for creating the database of equivalent verbal forms in the Russian-French multivariant parallel corpus // Информатика и её применения. - 2013. Т. 7. Вып. 2. Рp. 100-109.

6. Buntman N.V., Zaliznyak A.A., Zatsman I.M., Kruzhkov M.G., Loshilova E.Yu., Sichinava D.V. Information technologies of corpus research: principles of building cross-linguistic databases // Informati and its applications. - 2014, volume 8, issue 2. Pp. 98-110. DOI: https://doi.org/10.14357/19922264140210. (Boot options: IP: 213.230.114.157. August 17, 2019 8:50:00 PM)

7. Gochev G.N. Project "Corpus of Russian and Bulgarian Texts // Presidium of MAPRYAL: 2007-2010. Collection of scientific works. - SPb: Publishing House "MIRS", 2001. - 228 p. - Pp. 38-48.

8. A.A. Kokoreva Corpus of Parallel Texts in Foreign Language Teaching. - Bulletin of TSU (Tambov State University), issue 2 (118), 2013. - pp. 57-62.

9. Dobrovolskiy D. What tasks do parallel buildings solve? (Electron resource): https://postnauka.ru/video/54851

10. Krave M. F. Converbs in Contrast: Russian converb constructions and their English and Norwegian counterparts. PhD thesis. - 2011, University of Oslo. 